mystery of mysteries, and we have not yet approached its solution. But we must approach it ; for recurring pandemics of influenza like the recent one are more serious to civilised mankind than even the Great War.

\section{History of Electrotherapy.}

An Essay on the History of Electrotherapy and Diagnosis. By Hector A. Colwell. Pp. $x v+180$. (London : W. Heinemann (Medical Books) Ltd., I922.) I7s. $6 d$. net.

$\mathrm{N}_{\text {for the subject treated and this is handed of }}^{\mathrm{N} \text { essay }}$ to the reader who peruses it. Dr. Colwell has in some ways been fortunate in his subject, because it is one which yields to historical treatment when approached by a scholar. Of the evidences of this latter quality there is plenty of proof throughout this essay; there is a happy blending of historical accuracy, judgment in selection of facts, and a sense of the real importance of the subject of electrotherapy. The parent subject is now rather apt to be somewhat eclipsed by the more youthful one of radio-therapy, yet the benefit derived from electro-therapeutic measures in diagnosis and in the treatment of many diseases is a matter which need not be laboured.

Perhaps more than in any other branch of the healing art, the scientific advance of the subject to its present position has been one long series of spasmodic efforts interspersed between long periods of quiescence and indeed neglect. The neglect was probably the rational outcome of the conditions of quackery which often showed itself in the application of electricity to the ills of the human body. It is probably not very far from the truth to correlate this halting progress of the subject with the parallel state of affairs in the study and researches of a physical character into the nature of electricity itself.

It is interesting to read that a professor of physics, one Jallabert of Genoa, is to be regarded as the first scientific electrotherapist ; for it is a matter of history that, in $\mathbf{1 7 4 7}$, in collaboration with the surgeon Guyot, the electrical current was employed by him to produce muscular contractions in injured limbs, thus giving them the exercise necessary for the restoration of their normal functions. Though this is the case, the founding of modern electrotherapy occurred almost a century later as a result of the work of Duchenne of Boulogne.

The essay traces the growth of the subject to the present day. The last forty pages are devoted to the subject of radiology, but perhaps the lapse of time since the discovery of X-rays has been insufficient for a successful treatment of the subject on historical lines. Four pages of notes and an index complete a volume which is very well produced and illustrated by a number of plates of great individual interest.

The author is to be congratulated on an essay which marks out so clearly the milestones which have been passed and the obstructions which have been met in the journey of electrotherapy to its present-day status.

\section{Mustard Gas Poisoning.}

The Medical Aspects of Mustard Gas Poisoning. By Prof. A. S. Martin and Dr. C. V. Weller. Pp. 267. (London: Henry Kimpton, 1919.) 42s. net.

7 HIS volume is a belated account of investigations 1 carried out at Michigan during the war; 'in I9I 7 it would have been eagerly welcomed, at the date of publication which it bears it would have been decidedly interesting, at the present time it will only be so to specialists and historians. It tells, with a wealth of detail which seems needless, of the effects of $\beta$ - $\beta$-dichlorethyl sulphide, or mustard "gas," on various animals and on men accidentally gassed with it at factories in America where the substance was manufactured for gas offensive purposes during the war.

The substance is a general protoplasmic poison, readily penetrating the epidermis and other tissues; once inside the cells it is probably hydrolysed, and the extensive damage is due to local liberation of hydrochloric acid. The chief effects are therefore a destruction of all the cells with which the substance comes into contact; the eyes, lungs, and skin are the most likely to be affected, and the danger lies chiefly in the fact that the substance has but little smell, so that dangerous concentrations may be encountered without arousing suspicions in those unacquainted with the properties. As the substance is a liquid of high boiling-point, soil or other materials which have been fouled with it may remain a source of danger for days.

Treatment of the affected parts is directed chiefly to the alleviation of symptoms ; chlorine destroys the substance, so that local application of hypochlorites is useful in the treatment of skin burns, which are the most troublesome effects likely to be met with in men whose eyes and lungs are protected by the wearing of respirators.

The reviewer himself worked out the chief physiological effects of this substance on animals in the spring of I9I6, at the suggestion of his colleague Dr. H. W. Dudley; the results were reported through the proper channels, but were not published. The Germans first used the substance some fifteen months afterwards.

The work before us is the most complete and accurate NO. 2749, VOL. [ IO] 